\title{
Pregnane $\times$ Receptor (PXR) expression in colorectal cancer cells restricts irinotecan chemosensitivity through enhanced SN-38 glucuronidation
}

Caroline Raynal ${ }^{1,2}$, Jean-Marc Pascussi ${ }^{1}$, Géraldine Leguelinel ${ }^{1}$, Cyril Breuker ${ }^{1}$, Jovana Kantar ${ }^{3}$, Benjamin Lallemant ${ }^{1,4}$, Sylvain Poujol ${ }^{5}$, Caroline Bonnans ${ }^{1}$, Dominique Joubert ${ }^{1}$, Frédéric Hollande ${ }^{1}$, Serge Lumbroso ${ }^{1,2}$, Jean-Paul Brouillet ${ }^{1,2}$, Alexandre Evrard ${ }^{1,2^{*}}$

\begin{abstract}
Background: Clinical efficacy of chemotherapy in colorectal cancer is subjected to broad inter-individual variations leading to the inability to predict outcome and toxicity. The topoisomerase I inhibitor irinotecan (CPT-11) is worldwide approved for the treatment of metastatic colorectal cancer and undergoes extensive peripheral and tumoral metabolism. PXR is a xenoreceptor activated by many drugs and environmental compounds regulating the expression of drug metabolism and transport genes in detoxification organs such as liver and gastrointestinal tract. Considering the metabolic pathway of irinotecan and the tissue distribution of Pregnane $\times$ Receptor (PXR), we hypothesized that PXR could play a key role in colon cancer cell response to irinotecan.

Results: PXR mRNA expression was quantified by RT-quantitative PCR in a panel of 14 colon tumor samples and their matched normal tissues. PXR expression was modulated in human colorectal cancer cells LS174T, SW480 and SW620 by transfection and siRNA strategies. Cellular response to irinotecan and its active metabolic SN38 was assessed by cell viability assays, HPLC metabolic profiles and mRNA quantification of PXR target genes. We showed that PXR was strongly expressed in colon tumor samples and displayed a great variability of expression. Expression of hPXR in human colorectal cancer cells led to a marked chemoresistance to the active metabolite SN38 correlated with PXR expression level. Metabolic profiles of SN38 showed a strong enhancement of SN38 glucuronidation to the inactive SN38G metabolite in PXR-expressing cells, correlated with an increase of UDPglucuronosyl transferases UGT1A1, UGT1A9 and UGT1A10 mRNAs. Inhibition of PXR expression by lentivirusmediated shRNA, led to SN38 chemoresistance reversion concomitantly to a decrease of UGT1A1 expression and SN38 glucuronidation. Similarly, PXR mRNA expression levels correlated to UGT1A subfamily expression in human colon tumor biopsies.
\end{abstract}

Conclusion: Our results demonstrate that tumoral metabolism of SN38 is affected by PXR and point to potential therapeutic significance of PXR quantification in the prediction of irinotecan response. Furthermore, our observations are pharmacologically relevant since many patients suffering from cancer diseases are often exposed to co-medications, food additives or herbal supplements able to activate PXR. A substantial part of the variability observed among patients might be caused by such interactions

\footnotetext{
* Correspondence: alexandre.evrard@univ-montp1.fr

'Institut de Génomique Fonctionnelle, Centre National de la Recherche Scientifique (CNRS) UMR5203, Institut National de la Santé et de la Recherche Médicale (INSERM) U661, Université Montpellier 1 et 2, Montpellier F-34094, France
} 


\section{Introduction}

Colorectal cancer is the fourth most common cancer in men and the third in women worldwide, and is currently undergoing a rapid increase in incidence [1]. Approximately two-thirds of patients present potentially curable disease but $30-40 \%$ will relapse with metastatic disease. Despite the emergence of targeted therapies, chemotherapy based on conventional fluoropyrimidine associated either with the platinum salt oxaliplatin or with the topoisomerase inhibitor irinotecan remains the first-line treatment [2]. Yet, clinical efficacy of these drugs is limited by the inability to predict chemotherapy outcome and toxicity. Notably, broad inter-individual variations in terms of response as well as of the occurrence of severe toxic side-effects like diarrhea and neutropenia are detected following treatment with compounds such as irinotecan [3]. In this context, identification of biological markers allowing the prediction of both therapeutic and toxic response is a priority issue.

Irinotecan (or CPT-11) is a water-soluble derivative of camptothecin acting as a topoisomerase I inhibitor and currently registered for use in patients with metastatic colorectal cancer. Irinotecan itself has weak, if any, pharmacological activity in vitro. It is thought to exert its antitumor activity in vivo after enzymatic cleavage by carboxylesterases 1 and 2 (predominantly in the liver but also partly at the tumor site) that generate the active metabolite SN38. Irinotecan and SN38 are then subjected to extensive intracellular catabolism yielding inactive metabolites. Irinotecan undergoes phase I oxidation by cytochromes P450 3A4 and 3A5 leading to oxidized inactive metabolites whereas SN38 is metabolised to SN38G through phase II glucuronidation by the UDPglucuronosyl transferases 1A1, 1A6, 1A9 and 1A10 [4,5]. In addition, irinotecan and its metabolites are subjected to extracellular efflux through transporters, including Pglycoprotein (MDR1), multidrug resistance-related protein-2 (MRP2) and breast cancer resistance protein (BCRP) [6,7]. Numerous studies have focused on peripheral irinotecan metabolism, and genetic polymorphisms within genes coding for enzyme implicated in the irinotecan metabolic pathway have been extensively described. Notably, detection of the UGT1A1*28 genotype, found to be predictive for SN38 peripheral glucuronidation and irinotecan toxicity [8], is now recommended by the US Food and Drug Administration. However, conflicting results on UGT1A1*28 and the plethora of studies on others sequence variations in UGT1A1, but also in $A B C B 1, A B C C 1$ or $H N F 1 A$ genes, suggests that reliable predictions of SN38 exposures cannot be based on the detection of a single polymorphism [9]. Inter-individual variation may be due to a combination of many genetic and non-genetic factors (diet, co-medications, etc.). Indeed, irinotecan pharmacokinetics and disposition is affected by various compounds now identified as ligands of the xenosensor PXR (Pregnane $\times$ Receptor, NR1I2) such as rifampicin [10] or St. John's wort [11].

PXR is a nuclear receptor acting as a "molecular sentinel" able to bind to a large variety of structurally diverse compounds included drugs, food additive or environmental toxics [12]. It coordinates the detoxification of many lipophilic xenobiotics via transcriptional regulation of a large number of metabolizing enzymes and transporters [13]. Targets genes of PXR are CYP3A4 [14], MDR1 [15], CYP2B6 [16], members of UGTs superfamily [17] and transporters like the multidrug resistance-related protein-3 (MRP3) [18] or the organic anion transporting polypeptide-2 (OATP2) [19]. PXR is predominantly expressed in liver and in intestinal tract, but little is known about its expression in tumors. Because PXR controls the expression of key genes involved in anticancer drugs disposition, recent works have focused on its potential role in drug resistance [20]. For instance, PXR is suspected to play a role in both all-trans retinoic acid [21] and etoposide [22] resistances through an enhancement of their CYP3A4mediated metabolism. In addition, it has been shown that PXR induces cell proliferation and inhibits apoptosis in human colon cancer cells [23]. Considering the metabolic profile of irinotecan and the tissue distribution of PXR, we aimed to assess to what extent PXR could affect metabolism and colon cancer cell response to irinotecan. We show that expression of PXR in human colorectal cancer cells led to irinotecan and SN38 chemoresistance through enhancement of its glucuronidation.

\section{Materials and methods}

\section{Cell lines, plasmids and transfections}

The human colorectal cancer cells LS174T were kindly provided by Dr. Pierre Martineau (IRCM, Montpellier, France). SW480, SW620, HCT116, HT29, HepG2 and $\mathrm{HuH7}$ were from the cells collection of the Macromolecular Biochemistry Research Center (Montpellier, France). All cell lines were grown in RPMI 1640 supplemented with $10 \%$ fetal calf serum (FCS), $2 \mathrm{mmol} / \mathrm{l}$ glutamine, 100 units $/ \mathrm{ml}$ penicillin and streptomycin. Selection mediums for transfected cells were supplemented with $250 \mu \mathrm{g} / \mathrm{ml}$ (SW480 and SW620) or $500 \mu \mathrm{g} /$ $\mathrm{ml}$ (LS174T) geneticin. Cells were maintained routinely at $37^{\circ} \mathrm{C}$ in $5 \% \mathrm{CO} 2$ humidified atmosphere.

PXR expression vector was built by cloning hPXR-1 cDNA (NM_003889) [14] in a pcDNA3 vector (Invitrogen). Stable clones overexpressing PXR were obtained 
by transfecting cells with the pcDNA3-hPXR vector using lipofectamine LTX transfection reagent (Invitrogen), according to manufacturer's instructions. Parent LS174T cells were transfected with empty pcDNA3 vector to yield control mock-transfectant. The shRNAexpressing vectors were constructed by cloning shRNA expression cassettes into FG12 lentiviral vector [24] (additional file 1). Cells were transduced with lentiviral vectors and GFP positive cells were isolated using a BD FACSAria $^{\mathrm{TM}}$ cell sorter as previously reported [25].

\section{Human specimen samples}

Specimens of liver and colon biopsies were obtained from the pathologist after resection according to French government regulations and with approval of the ethical committee (Montpellier and Nîmes Hospitals). Informed consent was obtained from all patients. Tissue samples were stored in liquid nitrogen until further use.

\section{Chemicals}

Irinotecan, 5-fluorouracil (5-FU), oxaliplatin and verapamil chlorhydrate solutions were provided by the department of Pharmacy of the Nimes university hospital. SN38 was a kind gift from Dr E. Chatelut (Claudius Regaud Institute, Toulouse, France). Dimethysulfoxide (DMSO), rifampicin, ketoconazole, fumitremorgin $\mathrm{C}$ and L-Sulforaphane (SFN) were purchased from SigmaAldrich.

\section{RNA extraction and reverse transcription}

Total RNA were extracted using RNAeasy kit (Qiagen), according to the manufacturer's instructions. RNA quantity and quality of samples were determined by the 260:280 $\mathrm{nm}$ absorbance ratios using a NanoDrop spectrophotometer (Thermo Fisher Scientific). One $\mu \mathrm{g}$ of total RNA from each sample was added to $8.4 \mu \mathrm{l}$ of reverse transcription mix containing $4 \mu \mathrm{l}$ of first strand buffer $5 \times, 0.4 \mu \mathrm{l}$ of dNTP mix $25 \mathrm{mM}, 2 \mu \mathrm{l}$ of dithiothreitol $10 \times, 1 \mu$ l of oligodT primer solution and of MLV-RT enzyme $200 \mathrm{U} / \mu \mathrm{l}$. Solution volumes were adjusted to $20 \mu \mathrm{l}$ by adding RNase free water. Samples were placed at $37^{\circ} \mathrm{C}$ for 1 hour and at $65^{\circ} \mathrm{C}$ for 5 minutes. cDNA solution volumes were adjusted to $100 \mu \mathrm{l}$ by adding $80 \mu \mathrm{l}$ of PCR grade water and stored at $-20^{\circ} \mathrm{C}$ for further analysis.

\section{Real-time quantitative PCR}

mRNAs expression was evaluated by RT-quantitative PCR, using a LightCycler 480 real-time PCR system and SYBRGreen PCR master mix $2 \times$ (Roche Diagnostics) in 96-well plates. Quantitative PCR was done using genespecific primers and $\beta$-actin was used as reference gene (additional file 2). Standard curves were generated for all genes by serial dilution of cDNAs. After normalization of threshold cycle values with the amount of $\beta$-actin, gene expression levels were expressed as ratios compared with that of vehicle-treated cells. Each sample was run three times in duplicates, and data were analyzed using the 1.5 version of LightCycler 480 software (Roche Diagnostics). Standard curves were generated for all genes by serial dilution of cDNAs from LS174T control for relative quantification in cultured cells and from a pool of human liver biopsies for relative quantification in tumors.

\section{Western Immunoblotting}

Protein extracts were prepared from cells by using $M-$ $\mathrm{PER}^{\ominus}$ mammalian protein extraction reagent (Thermo Scientific) in presence of a protease inhibitor cocktail (Roche), according to the manufacturer's protocol. Proteins $(40 \mu \mathrm{g} /$ lane) were separated by $12 \%$ SDS-polyacrylamide gel electrophoresis and transferred to a PROTRAN $^{\circledR}$ nitrocellulose membrane (Schleicher and Schuell). Membranes were sequentially incubated with anti-hPXR (G-11, Santa Cruz Biotechnology) or anti$\beta$ actin (Santa Cruz Biotechnology) primary antibody, and with peroxidase-conjugated anti-mouse IgG (Santa Cruz Biotechnology). Signals were detected by chemoluminescence using ECL Western Blotting Detection reagents (GE Healthcare).

\section{Immunohistochemistry}

Tissues were embedded in paraffin and sections $(5 \mu \mathrm{m})$ were dewaxed in a xylene bath and rehydrated in graded alcohols. Endogenous peroxidase activity was quenched with $1.5 \% \mathrm{H}_{2} \mathrm{O}_{2}$ in methanol for $20 \mathrm{~min}$. and washed in PBS. Antigen retrieval was performed by boiling slides in $10 \mathrm{mM}$ sodium citrate buffer, $\mathrm{pH}$ 6.0. Nonspecific binding sites were blocked with 1\% BSA, 3\% normal goat serum, and $0.2 \%$ Triton X-100 in PBS for $1 \mathrm{~h}$ at RT. Slides were incubated with the primary anti-human polyclonal PXR antibody (Lifespan Biosiences) overnight at $4^{\circ} \mathrm{C}$ in 50 times-diluted blocking buffer. Universal immuno-peroxydase polymer anti-mouse Histofine ${ }^{\odot}$ (Nichirei Biosciences, Japan) was used as a secondary reagent, stainings were developed with DAB (brown precipitate, SIGMA) and hematoxylin counterstain was used. After dehydration, sections were mounted in Pertex (Histolab). Then, slides were scanned with high resolution Nanozoomer (Hamamatsu).

\section{Neutral red chemotherapeutic sensitivity assays}

Experimental conditions for neutral red assays were adapted from a previously described protocol [26]. Briefly, 20.000 cells were seeded in 96-well microtiter plates. After $24 \mathrm{~h}$ incubation, cells were treated for $72 \mathrm{~h}$ with increasing concentrations of cytotoxics. After a neutral red incubation at $37^{\circ} \mathrm{C}$ for four hours, cells were 
washed with PBS and destained with $150 \mu \mathrm{l}$ of $1 \%$ glacial acetic acid $/ 50 \%$ ethanol (vol:vol). The absorbance at $540 \mathrm{~nm}$ was measured using a microplate reader (iEMS, Labsystems). The effect of the drugs on cell survival was expressed as the percentage of cell viability compared to untreated cells.

\section{Irinotecan metabolites detection assay}

Cells were seeded in six-well plates at $10^{6}$ cells/well, incubated for 24 hours, and then treated with $0.1 \%$ DMSO (solvent) or $10 \mu \mathrm{M} \mathrm{SN} 38$ for $24 \mathrm{~h}$. Cell pellets and supernatants were stored at $-80^{\circ} \mathrm{C}$ for further analysis. Cell pellets were dissolved in $500 \mu$ l of a mixture of methanol-acetonitrile (50:50 vol:vol). $400 \mu \mathrm{l}$ of culture supernatants were added to $800 \mu \mathrm{l}$ of the mixture of methanol-acetonitrile (50:50 vol:vol). After proteins denaturation by full-speed vortex mixing, samples were then centrifuged at $13000 \mathrm{rpm}$ for 3 minutes. $550 \mu \mathrm{l}$ of clear supernatants were mixed to $250 \mu \mathrm{l}$ of $1 \mathrm{M} \mathrm{HCl}$ and used for HPLC injection. Irinotecan and its metabolites were detected and quantified by a HPLC method as previously described [27].

\section{Statistical analysis}

The Mann and Whitney test was used to analyze the difference between two groups of quantitative variables. Alpha value was set at $5 \%$. For comparisons among three groups of quantitative variables, the Kruskal Wallis test was used. In cases where there was a significant difference between the groups, a pairwise comparison was carried out by adjusting the alpha risk by the method of Bonferroni. Student's $t$-tests were performed when indicated in figures legends. All statistical analyses were carried out by the Department of biostatistics, epidemiology, public Health and medical information of the Nîmes University Hospital using the SAS software (SAS Institute Inc.).

\section{Results}

\section{Expression of hPXR in colon tissues and colon cancer cells}

To examine whether hPXR is expressed in human colon in vivo, we analyzed its mRNA expression in both normal and neoplastic human colon tissues. Human liver tissues, which are known to have high-PXR expression, were used as positives controls. As shown in figure 1A, PXR mRNA was detected in both normal and cancerous human colon tissues. In our panel of 14 patients, PXR mRNA was more abundant in some colon tissues than in liver biopsies, and displayed a greater variability in colon tissues than in liver tissues. Note that, although we did observe some quantitative differences between the expression of PXR in normal tissues and their matched colon tumour samples, we found no clear trend of tendency (figure 1B). In addition, we observed a very low expression of PXR mRNA in both colon cancer cells lines LS174T, SW480, SW620, or HT29 and hepatic cell lines HepG2 and HuH7 (figure 1C). This result on cell lines is in accordance with the previous observation that cultured cells often loose metabolic abilities and PXR expression [28]. Representative examples of PXR immunostaining are displayed in figure 1D, liver were used as positive control for PXR expression and negative controls without primary antibody are shown (photos a, c and d). We observed a strong immunostaining of PXR in both normal colon and tumors consistent with mRNA results.

\section{Functional characterization of PXR transfected LS174T colorectal cancer cells}

To decipher the role of PXR in irinotecan-mediated toxicity in colorectal cancer cells, we first established stable clones overexpressing hPXR in LS174T. These cells were chosen because of their low, but detectable, PXR mRNA expression, and their well known sensitiveness toward both irinotecan and SN38 [29]. In addition these cells express a functional p53 [30], which is partly involved in irinotecan response [31]. As shown in figure $2 \mathrm{~A}$, we selected three clones harbouring different PXR expression levels at both mRNA and protein levels (PXR2 $\approx$ PXR6 >> PXR3). Basal expression levels of CYP3A4 mRNA were higher (up to $9.31 \pm 2.40$ fold for PXR6) in PXR-expressing cells compared to controls (figure 2B) and were further increased by rifampicin $(48.92 \pm 1.07$ fold for PXR2, $19.02 \pm 6.83$ fold for PXR3 and $92.25 \pm 3.60$ fold for PXR6 compared to controls). In agreement with the very low level of endogenous PXR detected in these cells, we observed a very weak increase of CYP3A4 mRNA levels upon treatment of parent and pcDNA3-transfected cells with rifampicin. The growth rate of PXR-transfected cells did not significantly vary from that of pcDNA3-transfected cells (figure $2 \mathrm{C}$ )

\section{PXR induces colorectal cancer cells resistance to irinotecan and SN38}

To evaluate the role of PXR onto cell sensitivity to drugs used in the treatment of advanced colorectal cancer we first carried out neutral red cell viability assays. For this purpose, control and PXR-transfected LS174T clones were maintained for 72 hours in the presence of increasing concentrations of irinotecan, SN38, 5-fluorouracil or oxaliplatin. As shown in figure 3 , PXR expression clearly led to an increased survival of LS174T cells towards irinotecan and SN38, and the level of chemoresistance to SN38 was correlated to the relative PXR expression level of each clone (figure 3B). Upon treatment with $1 \mu \mathrm{M}$ SN38, PXR- 


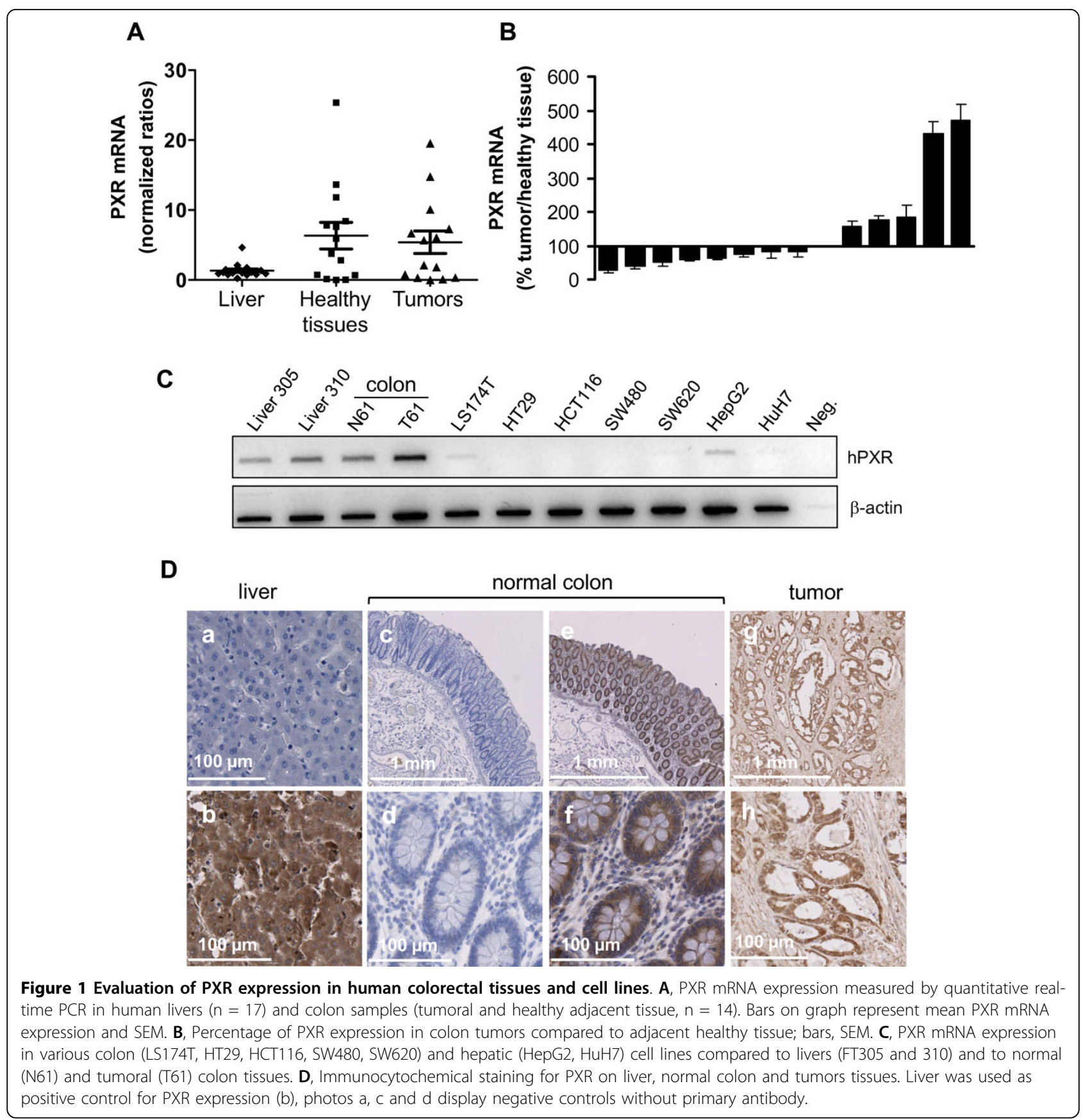

transfected cells displayed a 6-to 9-fold higher viability $(36.56 \% \pm 4.05$ surviving cells for PXR2 and $26.05 \% \pm$ 1.82 for PXR6) compared to pcDNA3-transfected cells $(3.93 \% \pm 1.64)$. We found no difference in topoisomerase I activity between pcDNA3-transfected cells and PXR-transfected cells demonstrating that the observed chemoresistance is not due to a variation of topoisomerase I expression after PXR transfection (additional file 3 )
As expected, cells were more sensitive to SN38 than to irinotecan, the latter undergoing minimal conversion into its active metabolite due to very low expression level of carboxylesterases in these cells (additional file 4). In addition, cell viability assays performed in SW480 and SW620 cell lines stably transfected with hPXR, showed similar PXR-dependent enhancement of SN38 resistance (additional file 5). On the other hand, we found no effect of PXR expression on cell sensitivity to 

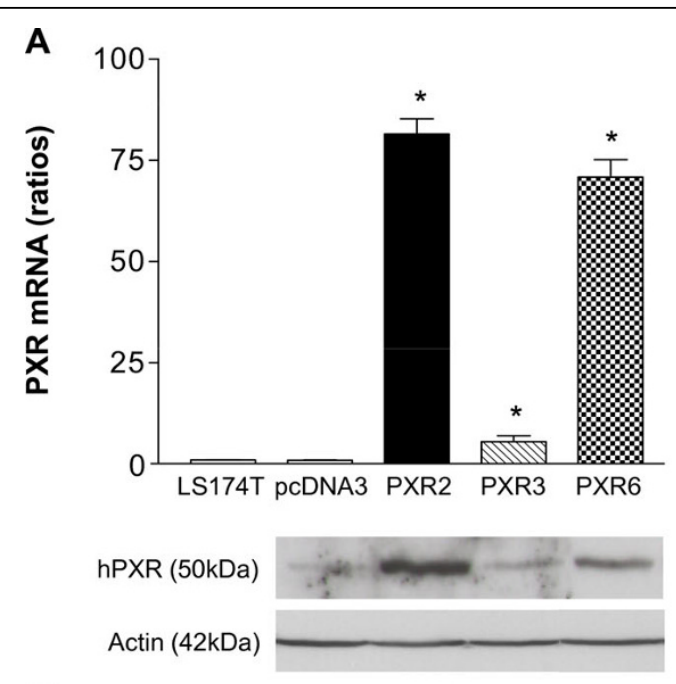

B

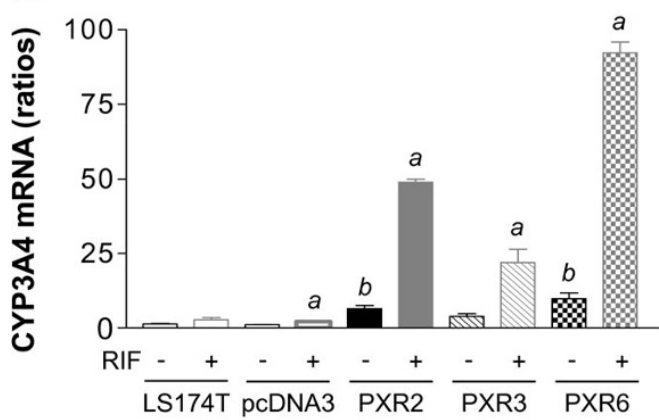

C

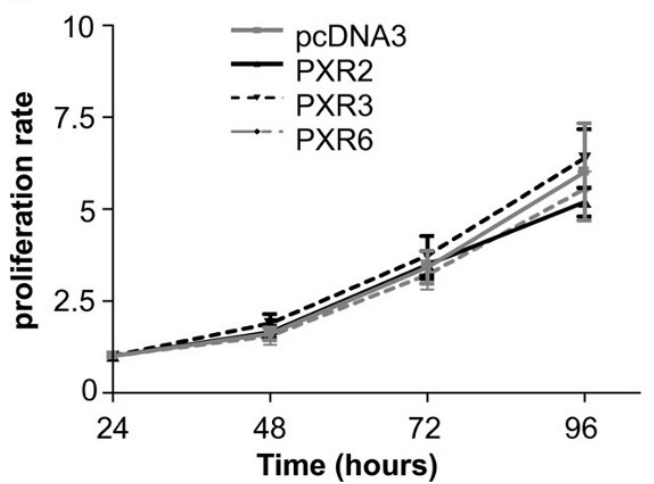

Figure 2 Characterization of LS174T PXR-transfected cells. A, PXR expression level in parent LS174T, pCDNA3-transfected and stable clones PXR2, PXR3 and PXR6 (top: mRNA expression level; bottom: protein expression level). ${ }^{*} p<0.05$, PXR expression of stable clones compared to parent and pcDNA3-transfected cells, assayed by Mann and Whitney test. B, CYP3A4 mRNA expression levels of CTRL and PXR overexpressing clones treated $24 \mathrm{~h}$ by solvent $(0.1 \% \mathrm{DMSO})$ or $10 \mu \mathrm{M}$ rifampicin in serum-free medium. Results were obtained from three separate experiments; bars, SEM. a, CYP3A4 expression of cells treated by rifampicin compared to the vehicle treated groups, $b$, CYP3A4 expression of vehicle treated stable clones compared to vehicle treated; assayed by Mann and Whitney test $(p<0.05)$. C, proliferation rate of cell lines. Cells were seeded in six-well plates at $5 \times 10^{5}$ cells/well and counted the indicated times after seeding (Z1 counter, Beckman Coulter). Data from three separate experiments; bars, SEM. both 5-fluorouracil and oxaliplatin sensitivities (additional file 6).

Surprisingly, we observed that rifampicin did not enhance the resistance of cells to SN38 (figure 4A). These observations suggest that activation of PXR is not required for these effects or that PXR is already activated under these conditions. While neither SN38 nor irinotecan activate PXR (additional file 7), we found that PXR was activated in our assays because of the presence of $10 \%$ fetal calf serum, as previously observed in the HepG2 cell line [32]. Accordingly, in presence of serum, CYP3A4 is highly expressed in PXR2 cells, with no additional effect of rifampicin, in contrast to what we observed in absence of serum (figure 4B). Moreover, we found that the pharmacological PXR inhibitor L-sulforaphane (SFN) [33] decreased the percentage of cell survival in PXR2 cells treated with 1 or $5 \mu \mathrm{M}$ SN38 $(15.13 \% \pm 3.99$ and $1.72 \% \pm 0.65)$, compared to cells treated with SN38 alone $(31.44 \% \pm 3.31$ and $9.32 \% \pm$ 1.14) (figure 4C). Although we cannot completely exclude off-target effects of SFN, it is likely that inhibition of PXR by SFN contributes toward decreased PXR2 cell resistance.

\section{Inhibition of PXR expression reverses chemoresistance to SN38}

Because SFN is known to affect several other signaling pathways, such as those involving the transcription factors Nrf2 [34] and NF-kappaB [35] that are known to affect cell sensitivity to cytotoxics, we then used a more specific strategy to inhibit PXR expression. For this purpose, LS174T-CTRL or PXR2 cells were transduced with control or shRNA-expressing lentiviral vectors as described in the material and methods section. Although PXR expression was partially decreased in PXR2 cells transduced with control FG12 virus (PXR2-mock) compared to the untransduced PXR2 clone (figure 5A), a stronger decrease was detected in PXR2 cells transduced with shRNA constructs selectively directed against the PXR mRNA. Thus, we observed that PXR2 cells transduced with the sh1334 construct presented a strong decrease of both PXR mRNA and protein levels, while PXR2 transduced with sh2116 displayed a moderate, if any, decrease of PXR expression. Accordingly, induction of CYP3A4 mRNA expression after rifampicin treatment in serum-free medium was observed in PXR2-mock and, to a lesser degree, in PXR2-sh2116 cells, but was lost in PXR2-sh1334 cells (figure 5B). In addition, we carried out neutral red viability assays on these clones (figure $5 \mathrm{C}$ ), and detected a strong reversion of chemoresistance to SN38 in PXR2-sh1334 cells at $0.1 \mu \mathrm{M}(6.56 \% \pm 1.75$ compared to $38.78 \pm 5.74$ in PXR2-mock), demonstrating that the inhibition of PXR expression by itself is sufficient to enhance chemosensitivity to SN38. 


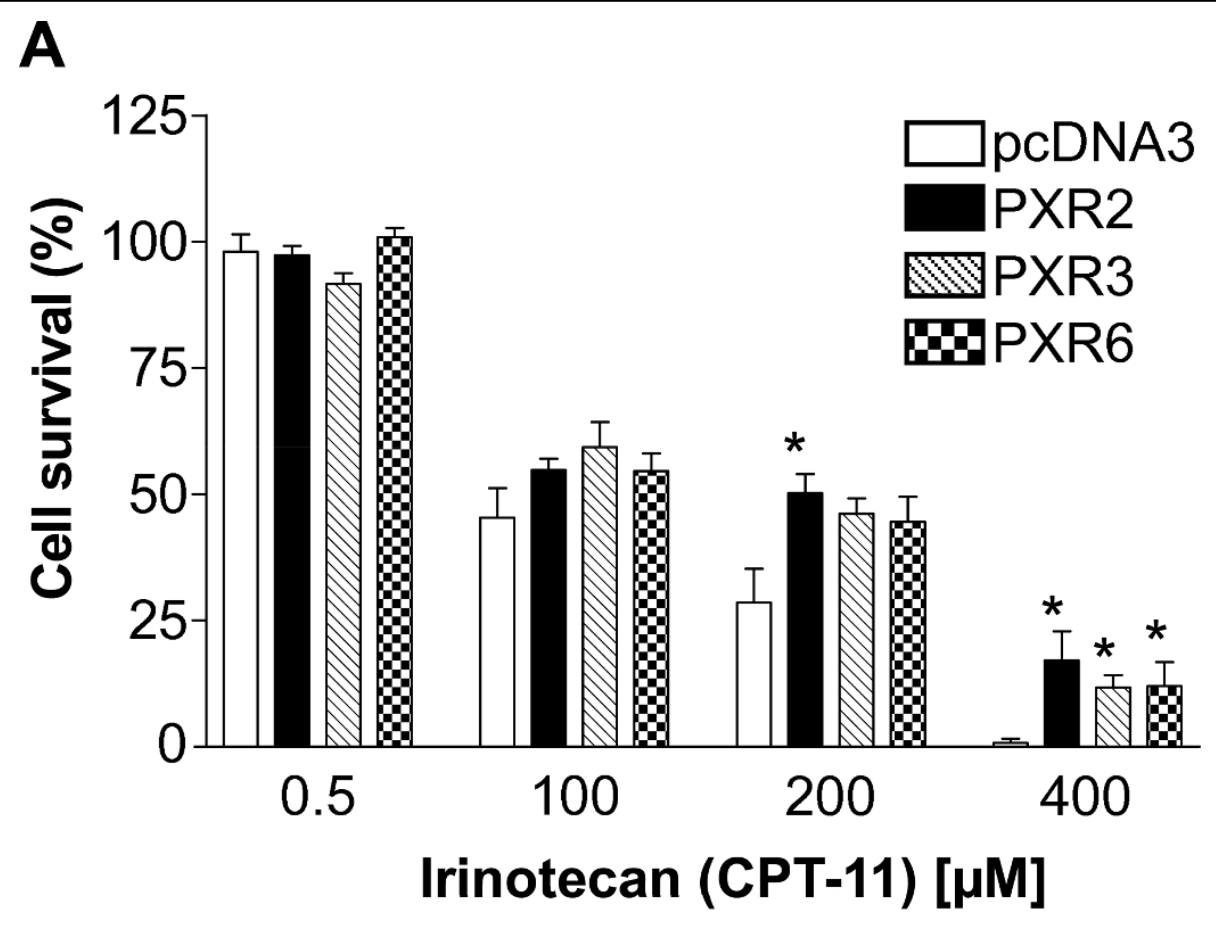

B

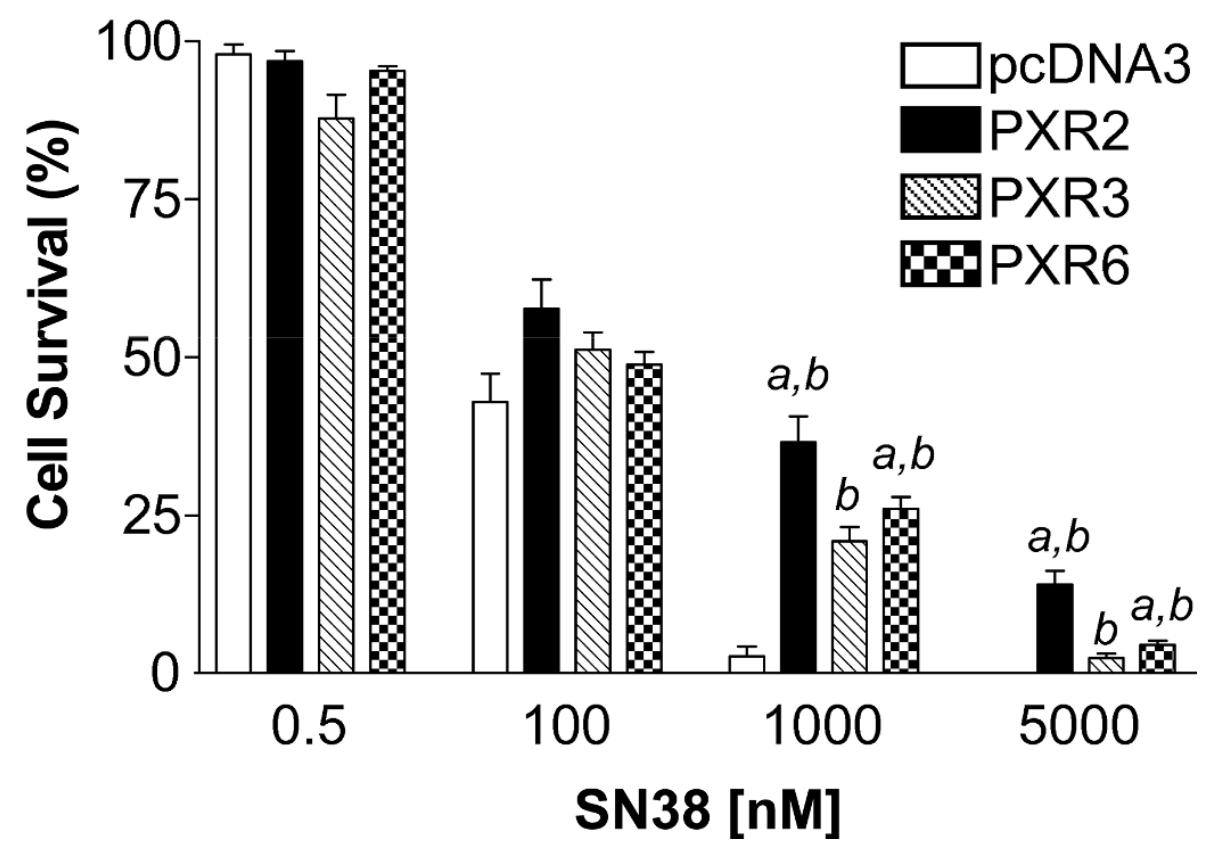

Figure 3 Increased chemoresistance in PXR overexpressing cells to irinotecan and SN38. For neutral red assays, cells were treated for $72 \mathrm{~h}$ by increasing concentrations of irinotecan (A) or SN38 (B). Columns, mean viability as a percentage of control (i.e., cells without

chemotherapeutics treatment, $100 \%)$ from replicates $(n=6)$ from six separate experiments; bars, SEM. $a$, viability percentages of PXR2, PXR3 and PXR6 compared to pcDNA3-transfected cells $(p<0.05$ ) (Mann and Whitney test). $b$, viability percentages of PXR2, PXR3 and PXR6 compared to each other using Kruskal Wallis test $(p<0.05)$. 


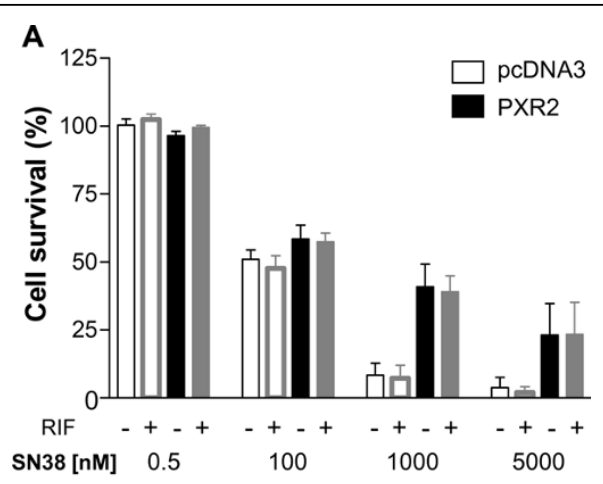

B

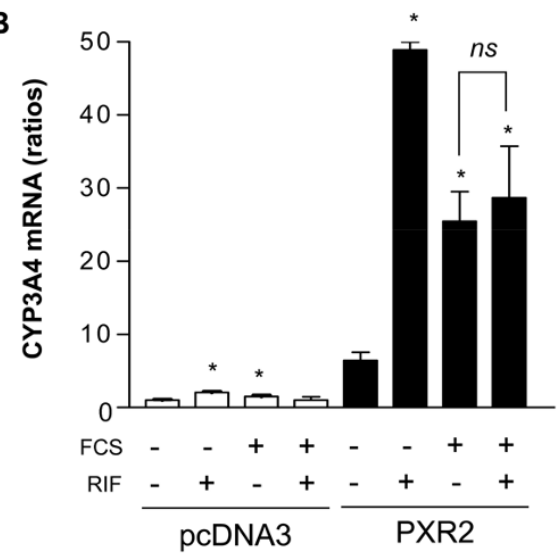

C

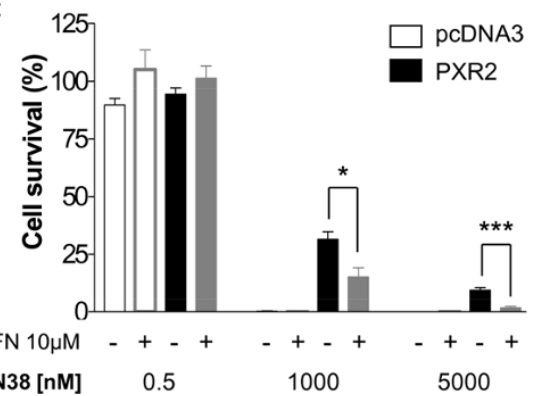

Figure $4 \mathrm{~A}$, cell viability assay on pcDNA3-transfected and PXR2 cells treated with rifampicin (RIF). Cells were cultured $24 \mathrm{~h}$ with DMSO $0.1 \%$ (solvent) or $10 \mu \mathrm{M}$ rifampicin in 10\% serum containing medium and then exposed to SN38 for $72 \mathrm{~h}$. Columns, mean viability as a percentage of control (i.e., cells without chemotherapeutics treatment, 100\%) from replicates $(n=6)$ from three separate experiments; bars, SEM. B, CYP3A4 mRNA expression level of pcDNA3-transfected or PXR-expressing cells cultured with $(10 \%)$ or without serum and treated with solvent $(0.1 \%$ DMSO) or $10 \mu \mathrm{M}$ rifampicin for $24 \mathrm{~h}$. Results were obtained from three separate experiments; bars, SEM. ${ }^{*} p<0.05$ (Mann and Whitney test), CYP3A4 mRNA expression of cells cultured with serum, with or without rifampicin compared to vehicle treated cells. C, cell viability assay on pcDNA3-transfected and PXR2 cells treated with PXR antagonist L-Sulforaphane (SFN). Cells were cultured in presence of solvent (DMSO $0.1 \%$ ) or $10 \mu \mathrm{M}$ L-Sulforaphane in serum containing medium for $24 \mathrm{~h}$ followed by the $72 \mathrm{~h}$ treatment of SN38 with or without SFN co-treatment. Columns, mean viability as a percentage of control (i.e., cells without chemotherapeutics treatment, 100\%) from replicates $(n=6)$ from three separate experiments; bars, SEM. ${ }^{* * *} p<0.001,{ }^{*} p<0.05$ (student's t-test).
A

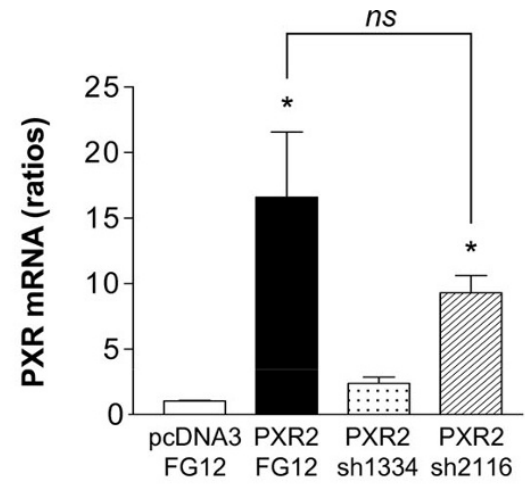

hPXR (50kDa)

Actin $(42 \mathrm{kDa})$

B

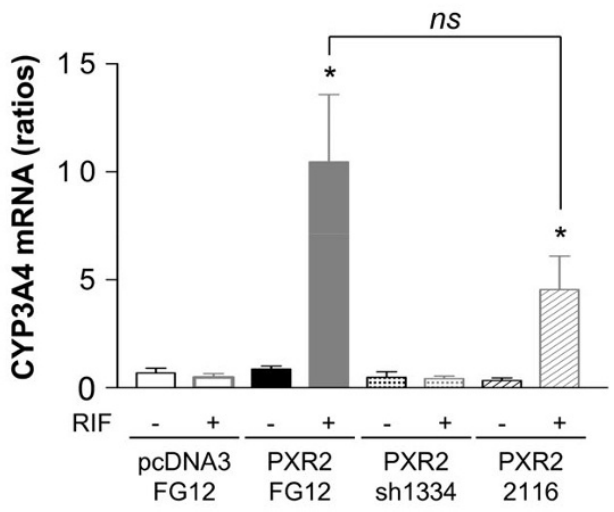

C

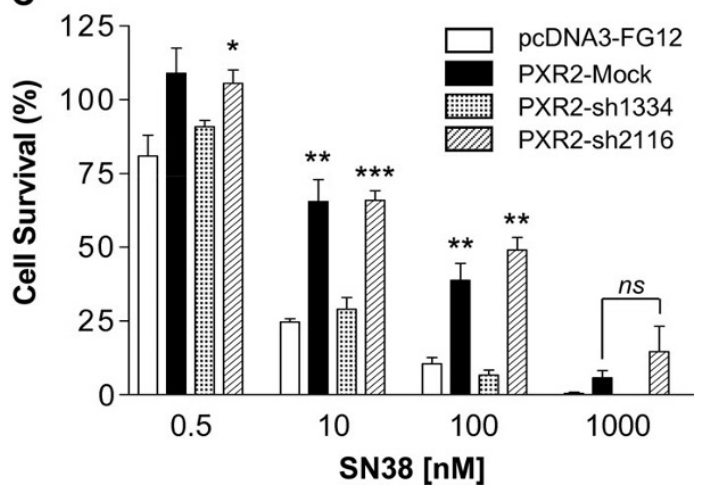

Figure 5 Reversion of chemoresistance in PXR2 by PXR shRNA

A, quantification of PXR expression by quantitative PCR (top) and western blot (bottom). ${ }^{*} p<0.05$ (Mann and Whitney test), PXR expression in PXR2-Mock, PXR2-sh1334 and PXR2-sh2116 cells compared to pcDNA3-Mock cells. B, quantification of CYP3A4 mRNA expression after treatment by solvent (DMSO $0.1 \%$ ) or $10 \mu \mathrm{M}$ rifampicin for $24 \mathrm{~h}$ in serum-free medium. ${ }^{*} \mathrm{p}<0.05$ (Mann and Whitney test), CYP3A4 expression of cells treated by rifampicin compared to the vehicle treated groups. C, cell viability assay on pcDNA3-Mock, PXR2-Mock, PXR2-sh1334 and PXR2-sh2116 toward SN38. Columns, mean viability as a percentage of control (i.e., cells without chemotherapeutics treatment, 100\%) from replicates $(n=6)$ from six separate experiments; bars, SEM. Student's t-test where performed between CTRL-mock cells to PXR2-Mock, PXR2-sh1334 and PXR2-sh2116: ${ }^{* *} p<0.001,{ }^{* *} p<0.01,{ }^{*} p<0.05$. 


\section{PXR increases SN38 glucuronidation}

Since PXR expression does not affect colon cancer cells proliferation, we hypothesized that SN38 resistance observed in PXR-expressing cells is likely mediated through transcriptional regulation of genes involved in drug metabolism. We first explored several steps of irinotecan metabolism by using pharmacological inhibitors of CYP3A4 (ketoconazole), MDR1 (verapamil) and BCRP (fumitremorgin C). None of these compounds was able to reverse the PXR-dependent chemoresistance (data not shown). We next assessed the metabolic profile of SN38 using a previously described chromatographic detection [27]. Raw data of peak area for intracellular and extracellular SN38 and SN38G allowed us to calculate the metabolic ratios SN38G/SN38.

Figure 6A displays relative proportions of total amounts (intra- and extracellular) of SN38 and SN38G. We found a very significant enhancement of SN38 glucuronidation in PXR-transfected cells. As shown in figure 6B, both intracellular and extracellular SN38G/SN38 ratios were significantly increased in cells overexpressing PXR concordant with PXR expression level of clones. Accordingly, PXR inhibition in PXR2-sh1334 cells resulted in a decrease of SN38G levels compared to those found in PXR2-mock or PXR2-sh2116 cells (figure 6C). Because the SN38G/SN38 ratio is a sensitive functional marker of UGT1A1, 6, 9 and 10 enzymes, we measured their relative expression by quantitative RTPCR. UGT1A1 mRNA expression was found to increase proportionally to the PXR expression levels in PXRtransfected cells (figure 7A). In addition, we also observed a lower, but significant overexpression of both UGT1A9 and UGT1A10 mRNA in those cells, while UGT1A6 mRNA was unaffected. In the same way, we observed a decrease of UGT1A1 mRNA expression in siRNA transfected cells (figure 7B). Taken together, these data strongly suggest that PXR significantly lowers SN38 concentration by increasing SN38 metabolism to its glucuronide conjugate, mainly through induction of UGT1A1.

\section{Discussion}

In this work, we address whether expression of PXR in human colorectal cancer cells could interfere with their sensitivity and metabolism of drugs used in treatment of advanced colorectal cancer. First we showed that hPXR is expressed in both normal and neoplastic human colon tissues with a strong variability in cancer colon tissues. This variability may prove clinically relevant, since a major finding of this study is that expression of PXR in human colorectal cancer cells leads to chemoresistance to the active metabolite of irinotecan, SN38, whereas it did not affect their sensitivity to both 5-fluorouracil and oxaliplatin sensitivities. The opposite effect obtained with pharmacological inactivation of PXR or shRNA-mediated PXR down regulation confirmed the direct involvement of PXR in SN38 chemoresistance. However, in contrast to previous studies showing that PXR affects intrinsic cell survival through the p53 signaling pathway [23] and cell growth [36], we found that PXR induced SN38 chemoresistance in LS174T ( $\left.553^{w t}\right)$ as well as in SW480 and SW620 (p53 $3^{m u t}$ ) without affecting their intrinsic proliferation rates. Instead, we observed that PXR expression lowered cellular SN38 concentration while increasing SN38 metabolism to its glucuronide conjugate. Accordingly, we found that several UGT1A isoenzymes were up-regulated in PXRexpressing cells, most notably UGT1A1 which is the key enzyme responsible of the inactivation of SN38 to SN38G.

Since PXR activation (or inhibition) appears to increase (or decrease) SN38 conversion to SN38G, our results highlight the central role of PXR in regulating the cytotoxic threshold of cells to irinotecan-based chemotherapy. Several studies have demonstrated that irinotecan pharmacokinetics and disposition are affected by various compounds now identified as PXR ligands such rifampicin [10], phenobarbital [37], valproic acid and other anticonvulsivant therapies $[38,39]$ or natural products including St. John's wort (Hypericum perforatum) [11]. In addition, our data are in accordance with previous studies reporting that intratumoral expression level of UGT1A isoforms may represent a mechanism of intrinsic irinotecan resistance in colon cancer $[40,41]$. Interestingly a significant $\left(\mathrm{r}^{2}=0.72, \mathrm{p}<0.001\right)$ correlation between PXR and UGT1A1 mRNA levels was found in human colon tumors (figure 8). Taken together, these data suggest that tumoral metabolism is potentially affected by environmental or diet stimuli and this should be taken into account in the prediction of irinotecan disposition in patients. In addition, it is known that diarrhea, a major limiting toxicity of irinotecan, is due to SN38 accumulation in enterocytes [42] and it is conceivable that in situ glucuronidation by tumors and adjacent tissues depends on PXR expression levels.

Considering its role as master xenobiotics responsive receptor linking DME genes expression to environment stimuli, we think that differences in PXR expression contribute to the well known intra- and inter-subject variability in irinotecan response, and that they participate in the difficulty to clearly identify factors responsible for pharmacogenetics of irinotecan, the so-called "irinogenetics" [43-45]. Indeed, environmental compounds, nutrition and diet affecting PXR expression and/or activation may mask or attenuate pharmacogenetic associations. Moreover, PXR itself display strong genetic polymorphism with more than 300 reported 


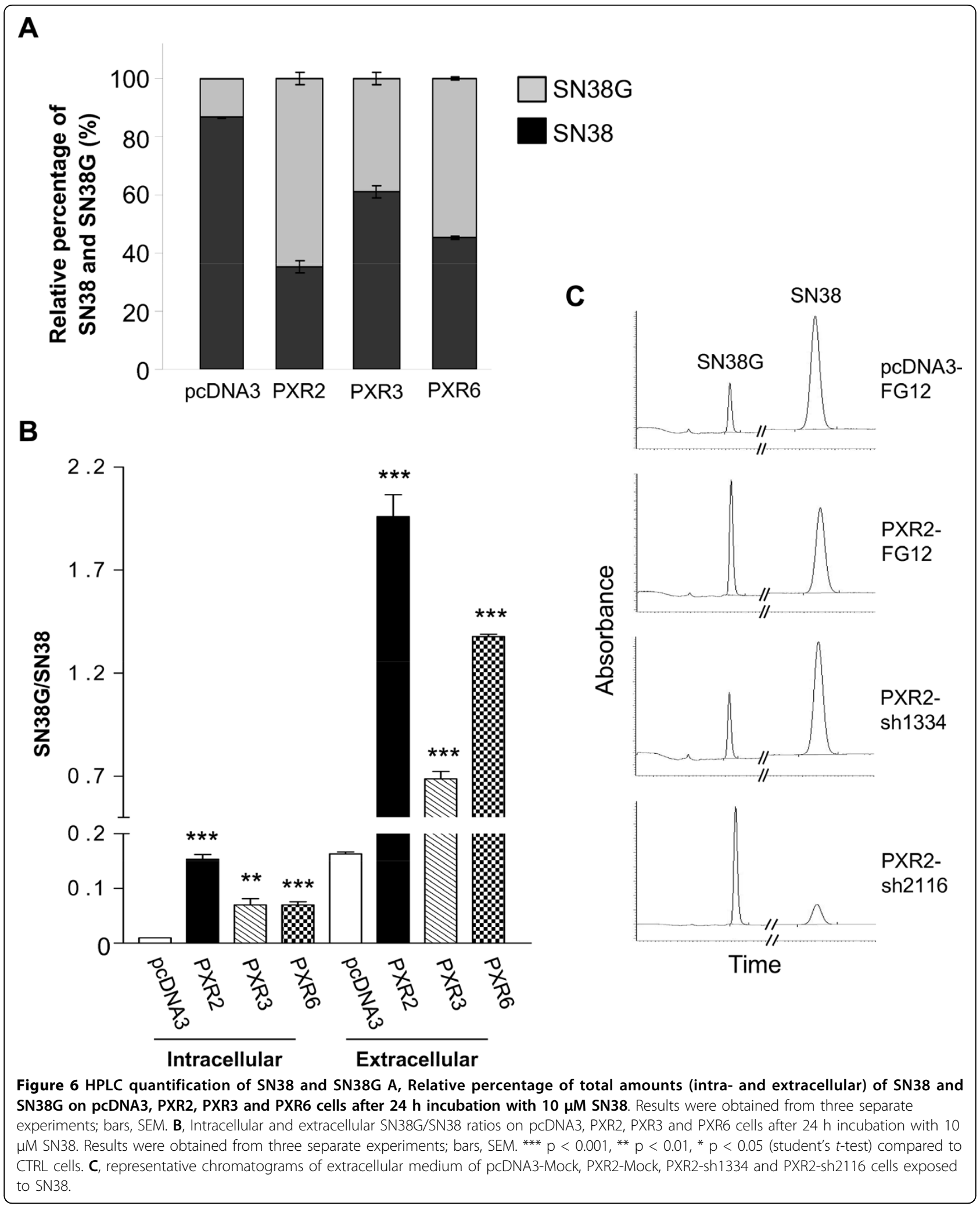




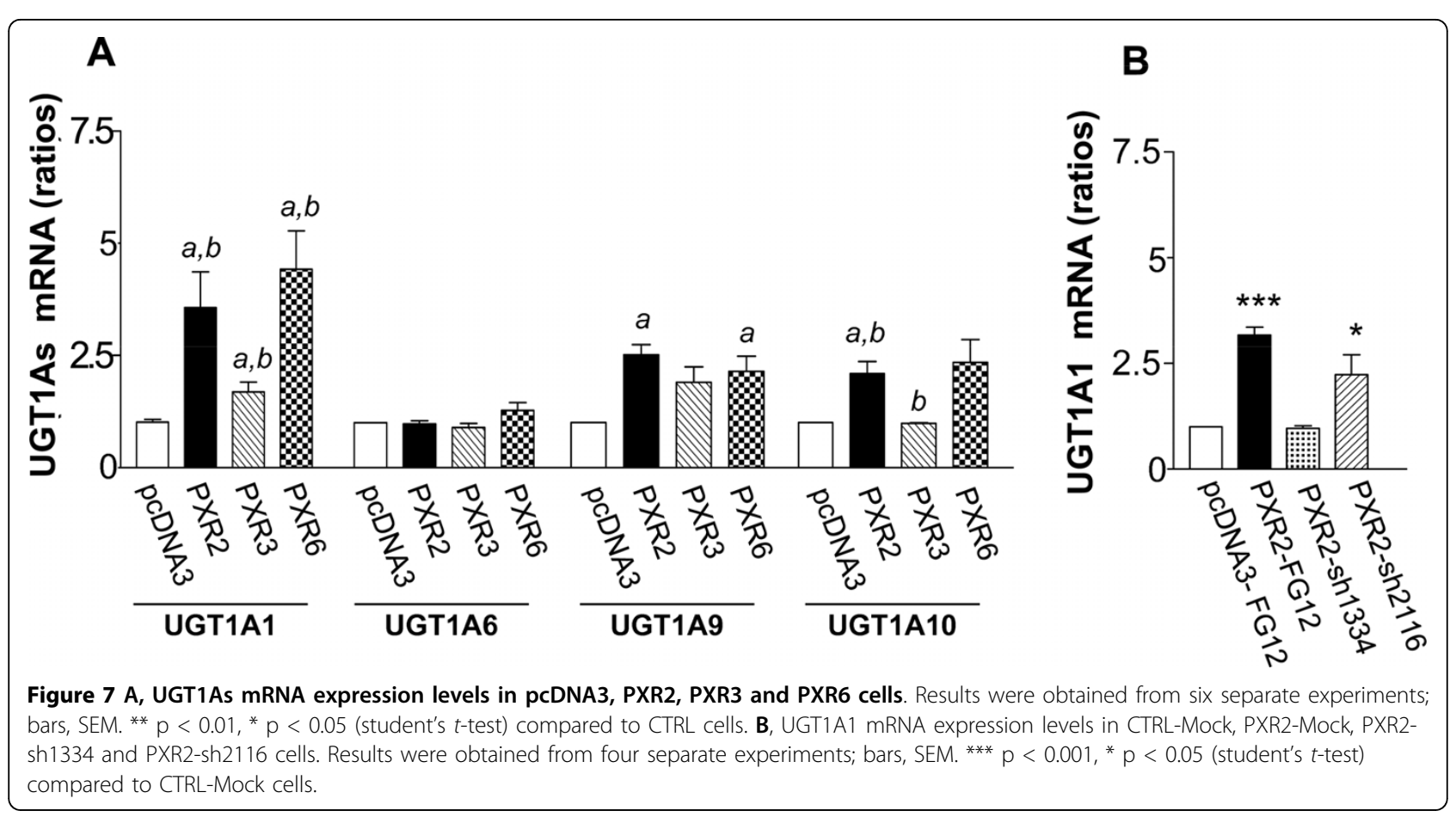

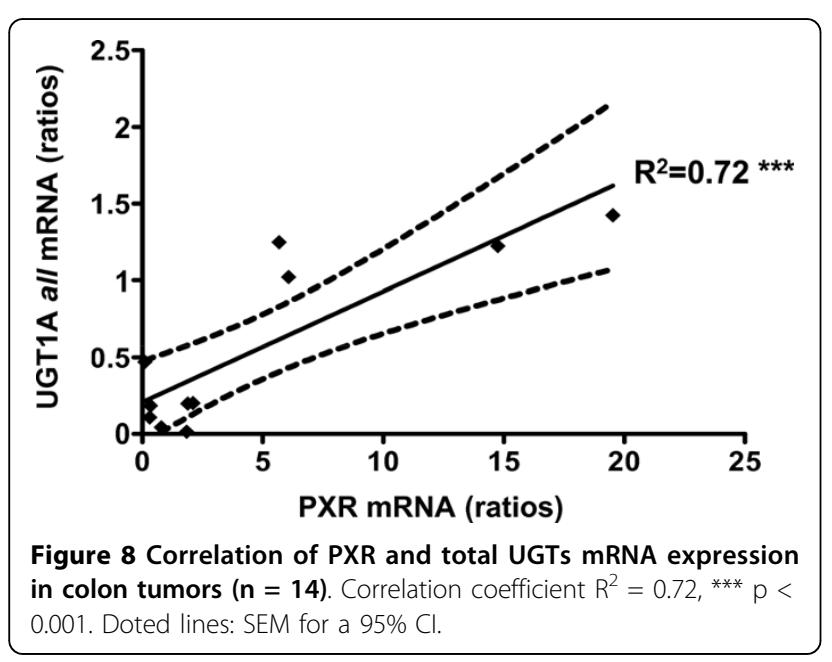

SNPs in the dbSNPs database, some of which well characterized and inducing differences in both gene expression and ligand recognition $[43,44]$. PXR expression levels within tumors could be also affected by nongenetic factors such as intra-tumor inflammatory cytokines [46], microRNA 148a [47] and methylation status of its exon 3 [48]. In this context, discriminating the roles of genetic influences from environmental effects in drug response, recently coined "pharmacoecology" [49], will be even harder as expected. Thus, it will be of interest to evaluate the relative importance of these genetic and non-genetic factors in patient response toward irinotecan-based chemotherapy.

\section{Conclusion}

In view of the present findings, clinical studies are now needed to evaluate the potential interest of PXR in personalized medicine. Indeed, PXR expression and/or activation level could help physicians in the choice of appropriate chemotherapy regimen for colorectal cancer patients, since therapeutic alternatives to irinotecan already exist (i.e. platinum salt or targeted therapy). Finally, PXR down-regulation could be considered as a novel therapeutic approach to circumvent chemoresistance to chemotherapy.

Additional file 1: Sequences of shRNA cassettes used for the inhibition of PXR expression. The shRNA-expressing vectors were constructed by cloning shRNA expression cassettes into FG12 lentiviral vector.

Click here for file

[http://www.biomedcentral.com/content/supplementary/1476-4598-9-46S1.PDF ]

Additional file 2: Primers sequences used for the quantification of PXR and its target genes by qPCR. mRNAs expression was evaluated by RT-quantitative PCR using a LightCycler 480 real-time PCR system and gene-specific primers, $\beta$-actin was used as reference gene.

Click here for file

[http://www.biomedcentral.com/content/supplementary/1476-4598-9-46S2.PDF ] 
Additional file 3: Topoisomerase I activity in LS174T pcDNA3 and PXR-transfected cells. Topoisomerase I activity was assessed by using a kit from TopoGen based on the ability of nuclear extracts to yield relaxed plasmid from supercoiled plasmid substrate DNA. Nuclear extracts from LS174T pcDNA3 and PXR-transfected cells were incubated for 15, 30 and 60 minutes with a supercoiled DNA marker subsequently subjected to agarose electrophoresis.

Click here for file

[ http://www.biomedcentral.com/content/supplementary/1476-4598-9-46S3.PDF ]

\section{Additional file 4: Carboxylesterases mRNA quantification}

Carboxylesterases (CES1 and CES2) expression level in LS174T pCDNA3 transfected-cells, stable clone PXR2 and a pool of cDNA extracted from liver biopsies. Results were obtained from six separate experiments; bars, SEM.

Click here for file

[http://www.biomedcentral.com/content/supplementary/1476-4598-9-46S4.PDF ]

Additional file 5: Characterization of SW480 and SW620 PXR-

transfected cells. A, C, PXR expression level in control and stable clones SW480-PXR1, SW620-1L and SW620-1H (U, undetectable PXR expression level). LS174T CTRL cells were taken as a calibrator for quantitative PCR. *** $\mathrm{p}<0.001$, PXR expression of stable clones compared to SW620 or SW480 control cells, assayed by Student's t-test. B, D, Increased chemoresistance in PXR overexpressing cells to SN38. For neutral red assays, cells were treated for $72 \mathrm{~h}$ by increasing concentrations of SN38. Columns, mean viability as a percentage of control (i.e., cells without chemotherapeutics treatment, 100\%) from replicates $(n=6)$ from three separate experiments; bars, SEM. ${ }^{*} \mathrm{p}<0.05$, viability percentages of PXRexpressing cells compared to control cells (Student's $t$-test).

Click here for file

[ http://www.biomedcentral.com/content/supplementary/1476-4598-9-46S5.PDF ]

Additional file 6: Cell viability assays of LS174T control and PXR expression cells, PXR2 and PXR6, to 5-FU and oxaliplatine. For

neutral red assays, cells were treated for $72 \mathrm{~h}$ by increasing

concentrations of 5-FU (A) or oxaliplatine (B). Columns, mean viability as a percentage of control (i.e., cells without chemotherapeutics treatment,

$100 \%)$ from replicates $(n=6)$ from three separate experiments; bars, SEM Click here for file

[http://www.biomedcentral.com/content/supplementary/1476-4598-9-46S6.PDF ]

\section{Additional file 7: CYP3A4 mRNA quantification after drug}

treatment. CYP3A4 mRNA expression levels in PCDNA3, PXR2, PXR3 and PXR6 cells after treatment with irinotecan or SN38. Results were obtained from six separate experiments; bars, SEM.

Click here for file

[ http://www.biomedcentral.com/content/supplementary/1476-4598-9-46S7.PDF ]

\section{Acknowledgements}

This work was funded by La Ligue contre le Cancer, Université Montpellier I and CHU Nîmes. We thank Jean-François Bourgaux, Christine Pignodel, Julie Pannequin for providing us colon tissues, Célia Basurko for statistical analysis and Françoise Malosse for helpful technical assistance for HPLC analysis.

\section{Author details}

'Institut de Génomique Fonctionnelle, Centre National de la Recherche Scientifique (CNRS) UMR5203, Institut National de la Santé et de la Recherche Médicale (INSERM) U661, Université Montpellier 1 et 2 Montpellier F-34094, France. ${ }^{2}$ Laboratoire de Biochimie, Centre Hospitalier Universitaire, Nîmes, F-30029 France. ${ }^{3}$ Laboratoire de Biochimie, Faculté de Médecine, Nîmes, F-30908 France. ${ }^{4}$ Service d'Oto-rhino-laryngologie, CHU Nîmes, F-30029 France. ${ }^{5}$ Service Pharmacie, Centre Régional de Lutte contre le Cancer Val d'Aurelle, Montpellier, F-34298 France.

\section{Authors' contributions}

CR and JMP designed and carried out most of the experiments and wrote the initial drafts of the manuscript. GL carried the cell viability assays studies on shRNA clones. CB (Breuker) carried out the western blots analysis of PXR. $J K$ and BL provided valuable help in RT-QPCR experiments. CB (Bonnans) carried out immunohistochemistry of PXR. SP supervised HPLC experiments. $\mathrm{DJ}$ and $\mathrm{FH}$ made original observations leading to this work and contributed to the critical revision of the manuscript. JPB and SL provided valuable reagents and devices and contributed to data interpretation. AE made first assumptions and contributed to the conception and design of the entire study and the final editing of the manuscript. All authors read and approved the final manuscript.

\section{Competing interests}

The authors declare that they have no competing interests.

\section{Received: 22 September 2009}

Accepted: 2 March 2010 Published: 2 March 2010

\section{References}

1. Center MM, Jemal A, Ward E: International trends in colorectal cancer incidence rates. Cancer Epidemiol Biomarkers Prev 2009, 18:1688-1694.

2. de Gramont A, Tournigand C, Andre T, Larsen AK, Louvet C: Adjuvant therapy for stage II and III colorectal cancer. Semin Oncol 2007, 34:S37-40.

3. Anthony L: Irinotecan toxicity. Curr Opin Support Palliat Care 2007, 1:35-39.

4. Ma MK, McLeod HL: Lessons learned from the irinotecan metabolic pathway. Curr Med Chem 2003, 10:41-49.

5. Mathiissen RH, van Alphen RJ, Verweij J, Loos WJ, Nooter K, Stoter G, Sparreboom A: Clinical pharmacokinetics and metabolism of irinotecan (CPT-11). Clin Cancer Res 2001, 7:2182-2194.

6. Candeil L, Gourdier I, Peyron D, Vezzio N, Copois V, Bibeau F, Orsetti B, Scheffer GL, Ychou M, Khan QA, Pommier Y, Pau B, Martineau P, Del Rio M: ABCG2 overexpression in colon cancer cells resistant to SN38 and in irinotecan-treated metastases. Int J Cancer 2004, 109:848-854.

7. Jansen WJ, Hulscher TM, van Ark-Otte J, Giaccone G, Pinedo HM, Boven E: CPT-11 sensitivity in relation to the expression of P170-glycoprotein and multidrug resistance-associated protein. Br J Cancer 1998, 77:359-365.

8. Innocenti F, Ratain MJ: "Irinogenetics" and UGT1A: from genotypes to haplotypes. Clin Pharmacol Ther 2004, 75:495-500.

9. Mathijssen RH, Gurney H: Irinogenetics: how many stars are there in the sky?. J Clin Oncol 2009, 27:2578-2579.

10. Yonemori K, Takeda Y, Toyota E, Kobayashi N, Kudo K: Potential interactions between irinotecan and rifampin in a patient with small-cell lung cancer. Int J Clin Oncol 2004, 9:206-209.

11. Mannel M: Drug interactions with St John's wort: mechanisms and clinical implications. Drug Saf 2004, 27:773-797.

12. Bertilsson G, Heidrich J, Svensson K, Asman M, Jendeberg L, SydowBackman M, Ohlsson R, Postlind H, Blomquist P, Berkenstam A: Identification of a human nuclear receptor defines a new signaling pathway for CYP3A induction. Proc Natl Acad Sci USA 1998, 95:12208-12213.

13. Willson TM, Kliewer SA: PXR, CAR and drug metabolism. Nat Rev Drug Discov 2002, 1:259-266.

14. Lehmann JM, McKee DD, Watson MA, Willson TM, Moore JT, Kliewer SA: The human orphan nuclear receptor PXR is activated by compounds that regulate CYP3A4 gene expression and cause drug interactions. $J$ Clin Invest 1998, 102:1016-1023.

15. Geick A, Eichelbaum M, Burk O: Nuclear receptor response elements mediate induction of intestinal MDR1 by rifampin. J Biol Chem 2001, 276:14581-14587.

16. Goodwin B, Moore LB, Stoltz CM, McKee DD, Kliewer SA: Regulation of the human CYP2B6 gene by the nuclear pregnane $\times$ receptor. $\mathrm{Mol}$ Pharmacol 2001, 60:427-431.

17. Gardner-Stephen D, Heydel JM, Goyal A, Lu Y, Xie W, Lindblom T, Mackenzie P, Radominska-Pandya A: Human PXR variants and their differential effects on the regulation of human UDPglucuronosyltransferase gene expression. Drug Metab Dispos 2004, 32:340-347.

18. Teng $S$, Jekerle $V$, Piquette-Miller M: Induction of ABCC3 (MRP3) by pregnane $\times$ receptor activators. Drug Metab Dispos 2003, 31:1296-1299. 
19. Ma X, Idle JR, Gonzalez FJ: The pregnane $\times$ receptor: from bench to bedside. Expert Opin Drug Metab Toxicol 2008, 4:895-908.

20. Chen $Y$, Nie D: Pregnane $\times$ receptor and its potential role in drug resistance in cancer treatment. Recent Pat Anticancer Drug Discov 2009, 4:19-27.

21. Wang T, Ma X, Krausz KW, Idle JR, Gonzalez FJ: Role of pregnane $\times$ receptor in control of all-trans retinoic acid (ATRA) metabolism and its potential contribution to ATRA resistance. J Pharmacol Exp Ther 2008, 324:674-684.

22. Mensah-Osman EJ, Thomas DG, Tabb MM, Larios JM, Hughes DP, Giordano TJ, Lizyness ML, Rae JM, Blumberg B, Hollenberg PF, Baker LH: Expression levels and activation of a PXR variant are directly related to drug resistance in osteosarcoma cell lines. Cancer 2007, 109:957-965.

23. Zhou J, Liu M, Zhai Y, Xie W: The antiapoptotic role of pregnane $x$ receptor in human colon cancer cells. Mol Endocrinol 2008, 22:868-880.

24. Qin XF, An DS, Chen IS, Baltimore D: Inhibiting HIV-1 infection in human T cells by lentiviral-mediated delivery of small interfering RNA against CCR5. Proc Natl Acad Sci USA 2003, 100:183-188.

25. Moreau A, Teruel C, Beylot M, Albalea V, Tamasi V, Umbdenstock T, Parmentier Y, Sa-Cunha A, Suc B, Fabre JM, Navarro F, Ramos J, Meyer U, Maurel P, Vilarem MJ, Pascussi JM: A novel pregnane $\times$ receptor and S14mediated lipogenic pathway in human hepatocyte. Hepatology 2009.

26. Evrard A, Cuq P, Ciccolini J, Vian L, Cano JP: Increased cytotoxicity and bystander effect of 5-fluorouracil and 5-deoxy-5-fluorouridine in human colorectal cancer cells transfected with thymidine phosphorylase. $\mathrm{Br} J$ Cancer 1999, 80:1726-1733.

27. Poujol S, Pinguet F, Malosse F, Astre C, Ychou M, Culine S, Bressolle F: Sensitive HPLC-fluorescence method for irinotecan and four major metabolites in human plasma and saliva: application to pharmacokinetic studies. Clin Chem 2003, 49:1900-1908.

28. Pascussi JM, Jounaidi Y, Drocourt L, Domergue J, Balabaud C, Maurel P, Vilarem MJ: Evidence for the presence of a functional pregnane $X$ receptor response element in the CYP3A7 promoter gene. Biochem Biophys Res Commun 1999, 260:377-381.

29. Jansen WJ, Zwart B, Hulscher ST, Giaccone G, Pinedo HM, Boven E: CPT-11 in human colon-cancer cell lines and xenografts: characterization of cellular sensitivity determinants. Int I Cancer 1997, 70:335-340.

30. Arita D, Kambe M, Ishioka C, Kanamaru R: Induction ofp53-independent apoptosis associated with G2M arrest following DNA damage in human colon cancer cell lines. Jpn J Cancer Res 1997, 88:39-43.

31. McDonald AC, Brown R: Induction of p53-dependent andp53independent cellular responses by topoisomerase 1 inhibitors. $\mathrm{Br} J$ Cancer 1998, 78:745-751.

32. Pascussi JM, Drocourt L, Gerbal-Chaloin S, Fabre JM, Maurel P, Vilarem MJ: Dual effect of dexamethasone on CYP3A4 gene expression in human hepatocytes. Sequential role of glucocorticoid receptor and pregnane $x$ receptor. Eur J Biochem 2001, 268:6346-6358.

33. Zhou C, Poulton EJ, Grun F, Bammler TK, Blumberg B, Thummel KE, Eaton DL: The dietary isothiocyanate sulforaphane is an antagonist of the human steroid and xenobiotic nuclear receptor. Mol Pharmacol 2007, 71:220-229.

34. Morimitsu $Y$, Nakagawa $Y$, Hayashi $K$, Fujii $H$, Kumagai T, Nakamura $Y$, Osawa T, Horio F, Itoh K, lida K, Yamamoto M, Uchida K: A sulforaphane analogue that potently activates the Nrf2-dependent detoxification pathway. J Biol Chem 2002, 277:3456-3463.

35. Xu C, Shen G, Chen C, Gelinas C, Kong AN: Suppression of NF-kappaB and NF-kappaB-regulated gene expression by sulforaphane and PEITC through IkappaBalpha, IKK pathway in human prostate cancer PC-3 cells. Oncogene 2005, 24:4486-4495.

36. Masuyama H, Nakatsukasa H, Takamoto N, Hiramatsu Y: Down-regulation of pregnane $\times$ receptor contributes to cell growth inhibition and apoptosis by anticancer agents in endometrial cancer cells. Mol Pharmacol 2007, 72:1045-1053.

37. Gupta E, Wang X, Ramirez J, Ratain MJ: Modulation of glucuronidation of SN-38, the active metabolite of irinotecan, by valproic acid and phenobarbital. Cancer Chemother Pharmacol 1997, 39:440-444.

38. Crews KR, Stewart CF, Jones-Wallace D, Thompson SJ, Houghton PJ, Heideman RL, Fouladi M, Bowers DC, Chintagumpala MM, Gajjar A: Altered irinotecan pharmacokinetics in pediatric high-grade glioma patients receiving enzyme-inducing anticonvulsant therapy. Clin CancerRes 2002, 8:2202-2209
39. de Jong FA, Bol van der JM, Mathijssen RH, Loos WJ, Mathot RA, Kitzen JJ, Bent van den $\mathrm{MJ}$, Verweij J: Irinotecan chemotherapy during valproic acid treatment: pharmacokinetic interaction and hepatotoxicity. Cancer Biol Ther 2007, 6:1368-1374.

40. Cummings J, Boyd G, Ethell BT, Macpherson JS, Burchell B, Smyth JF, Jodrell DI: Enhanced clearance of topoisomerase I inhibitors from human colon cancer cells by glucuronidation. Biochem Pharmacol 2002, 63:607-613.

41. Cummings J, Ethell BT, Jardine L, Boyd G, Macpherson JS, Burchell B, Smyth JF, Jodrell Dl: Glucuronidation as a mechanism of intrinsic drug resistance in human colon cancer: reversal of resistance by food additives. Cancer Res 2003, 63:8443-8450.

42. Gupta E, Lestingi TM, Mick R, Ramirez J, Vokes EE, Ratain MJ: Metabolic fate of irinotecan in humans: correlation of glucuronidation with diarrhea. Cancer Res 1994, 54:3723-3725.

43. Mathijssen RH, Gurney H: Irinogenetics: How Many Stars Are There in the Sky?. J Clin Oncol 2009.

44. Bosch TM, Deenen M, Pruntel R, Smits PH, Schellens JH, Beijnen JH, Meijerman I: Screening for polymorphisms in the PXR gene in a Dutch population. Eur J Clin Pharmacol 2006, 62:395-399.

45. King CR, Xiao M, Yu J, Minton MR, Addleman NJ, Van Booven DJ, Kwok PY, McLeod HL, Marsh S: Identification of NR112 genetic variation using resequencing. Eur J Clin Pharmacol 2007, 63:547-554.

46. Moreau A, Vilarem MJ, Maurel P, Pascussi JM: Xenoreceptors CAR and PXR activation and consequences on lipid metabolism, glucose homeostasis, and inflammatory response. Mol Pharm 2008, 5:35-41.

47. Takagi S, Nakajima M, Mohri T, Yokoi T: Post-transcriptional regulation of human pregnane $\times$ receptor by micro-RNA affects the expression of cytochrome P450 3A4. J Biol Chem 2008, 283:9674-9680.

48. Misawa A, Inoue J, Sugino $Y$, Hosoi H, Sugimoto T, Hosoda F, Ohki M, Imoto I, Inazawa J: Methylation-associated silencing of the nuclear receptor 112 gene in advanced-type neuroblastomas, identified by bacterial artificial chromosome array-based methylated $\mathrm{CpG}$ island amplification. Cancer Res 2005, 65:10233-10242.

49. Flexner C: Pharmacoecology: a new name for an old science. Clin Pharmacol Ther 2008, 83:375-379.

\section{doi:10.1186/1476-4598-9-46}

Cite this article as: Raynal et al.: Pregnane $\times$ Receptor (PXR) expression in colorectal cancer cells restricts irinotecan chemosensitivity through enhanced SN-38 glucuronidation. Molecular Cancer 2010 9:46.

\section{Submit your next manuscript to BioMed Central and take full advantage of:}

- Convenient online submission

- Thorough peer review

- No space constraints or color figure charges

- Immediate publication on acceptance

- Inclusion in PubMed, CAS, Scopus and Google Scholar

- Research which is freely available for redistribution
C Biomed Central 